\title{
Dyret i dekonstruktionen
}

Kun poesien kan meget kort sige det, som er meget langt. Poetikken, derimod, er lang og tung af tradition: den høje stil, de sublime genrer, metrikkens love, figurernes taksonomi. Poetikken er et bygningsværk, som rækker ind i himlen. Der bor alle epokers svar på spørgsmålet: Hvad er poesi?

Spørg endnu en gang: "Hvad er..." - forudsæt endnu en gang, at der kan gives et klart svar, hvilket igen forudsætter, at tingen er det, som den er, og in casu at poesien er det, som den er. Et sådant spørgsmål sørger over poesiens død og ønsker prosaen velkommen. Således ender Derridas måske allerkorteste dekonstruktion, Che cos'è la poesia?

Han var blevet udfordret af det italienske tidsskrift Poesia til kort at forklare - en deux mots, som det hedder på fransk - hvad poesi er. Filosoffen svarer med at skrive en fabel. For at blive i stand til at tage imod digtets gave - den som kommer, når du mindst venter det - må du ned på jordniveau, til det som sætter sig langsomt i bevægelse i halvmørket, ved daggry eller i skumringstimen, du må ned til det laveste og ubetydeligste, det næsten usynlige. Digtet kryber normalt omkring alene på små stier blandt buske og krat, men samtidig beder det om at blive læst, det vil oversættes, sættes over til mig, fortolkes og forstås; dermed lever det lige så farligt som et pindsvin på vej over til den anden side af motorvejen. Og når en fare nærmer sig, ruller såvel digtet som pindsvinet sig sammen til en bold med alle pindene ude, en latterligt absurd måde at beskytte sig mod biler på. Ingen af dem er fulgt med tiden, de ved ikke, at biler eller anden motorvejsprosa overhovedet ikke lader sig skræmme af pinde. En så anakronistisk måde at beskytte sig på må nødvendigvis ende i katastrofe. Med Derridas ord: en distræt apokalypse, det vil sige omflakkende, tankeløs, som når man har tankerne andre steder. Distræt og desuden diskret: et pindsvin som skovbundens svar på Dyret i Åbenbaringen.

Forbilledlig kort er denne tekst. Filosoffen, i anledningen digter i mødet med digtet, mobiliserer straks ordenes semantiske og klanglige kraft, sætter metaforene i spil, veksler mellem udsigelsespositioner og bevæger sig i skrå bevægelser fra tanke 
til billede til tanke, mens det ene ord tager det andet. I denne skrift kredses poesiens hjerte ind, i en besværgende poetisk prosa, mens kulturen udsættes for overlagt glemsel, og poetikkens bibliotek sættes i brand. Det, som stod i centrum og fyldte, falder sammen, så vi kan få øje på det lille væsen i udkanten, i grænseområdet, på de små stier i krattet ved motorvejen, dernede i skæringspunktet mellem tryghed og den visse død.

Repetition af Derridas svar "i to ord" formuleret som to aksiomer: 1. Et digt skal være kort, elliptisk, fortættet. Både en Verdichtung (tysk og uoversætteligt langt ind i digtets ubevidste) og en retrait (fransk og uoversættelig sammentrækning og tilbagetrækning til det sammenkrøbnes hemmelige tilholdssted). 2. Et digt skal have hjerte. Hjertet som bærer apprendre par cœur eller learn by heart. Aksiom 2 ruller sig ind i aksiom 1. Digtet siger "lær mig udenad!" Hjertet forlanger en liturgi, som mimer mekanikkens udvendighed: auswendig (udenad). Glem alt andet, bare recitér mig. Reproducér mig som et elsket spor. "Et hjerte dernede, mellem stierne eller motorvejene, uden for din nærhed, ydmygt, tæt ved jorden, helt nederst. gentag mumlende: sig det ikke til nogen..."

Derrida balancerer på grænsen til det sentimentale, vi bliver bevæget (det var vel meningen) og får lyst, også vi, til at løfte det lille pindsvin - så alene og sårbart! - op og bære det væk til et trygt sted. Afstanden til andre sakrificielle dyr er enorm. Her er ingen hvid hind, ingen kronhjort eller andre stærke og raske, stolte dyr, som ofres for at formilde eller tilfredsstille en gud i hans lune. Heller ingen triumferende dyr; Derrida nævner fugl Føniks og ørnen som kategorier, han har forkastet. Pindsvinet skal læses som en synekdoke, et lånt navn for noget, som ikke selv har noget navn. Den inderste og dybeste hemmelighed, den som forbliver hemmelig, selv når den siges videre: gentages, reciteres, messes mumlende som en bøn - denne hemmelighed deponeres i det mest undseelige, uanselige og ufashionable af alle dyr.

Hvordan kan noget forblive hemmeligt, samtidig med at det fortælles videre? Denne gåde vender Derrida tilbage til, i for eksempel Demeure, hvor den ubestemmelige position mellem digtning og sandhed, fiktion og vidnesbyrd, forsvares og simpelthen pålægges os, fordi vidnesbyrdet ellers ville reduceres til bevis, information, dokument, og miste sig selv som bevidnelse og udsigelse. Der findes ikke noget vidnesbyrd, som ikke strukturelt indebærer en mulighed for fiktion, forstillelse og løgn, det vil sige digtning. Sandheden må hjemsøges af løgnen for at forblive vidnesbyrd, åbne sig for muligheden for at være opdigtet. På denne flydende grænse må vi forblive (demeurer); det er den, som forener vidnesbyrdet med hemmeligheden. Det, jeg vidner om, må være noget, kun jeg kan vidne om, ingen kan vidne i mit sted. Det er min hemmelighed, og jeg må kunne hemmeligholde selve det, jeg vidner om, og selv det, jeg vidner om. Hemmeligheden forudsætter ikke kun, at der er et vidne til stede, som kan dele hemmeligheden, men også at vidnet må forpligte sig til at holde den hemmelig: ikke sige det til nogen. At dele en hemmelighed indebærer en bevaring af den, en hemmeligholdelse.

Ud fra verbet demeurer med afledninger: demeure, à demeure, en demeure... og alle de betydninger, dette sætter i spil, videreudvikler Derrida vidnesbyrdets gåde. Den ligger tapie dans l'ombre de ses syllables (sammenkrøbet i disse stavelsers mørke), som et dyr, kan vi tilføje, et dyr, vi synes, at vi kender allerede. 


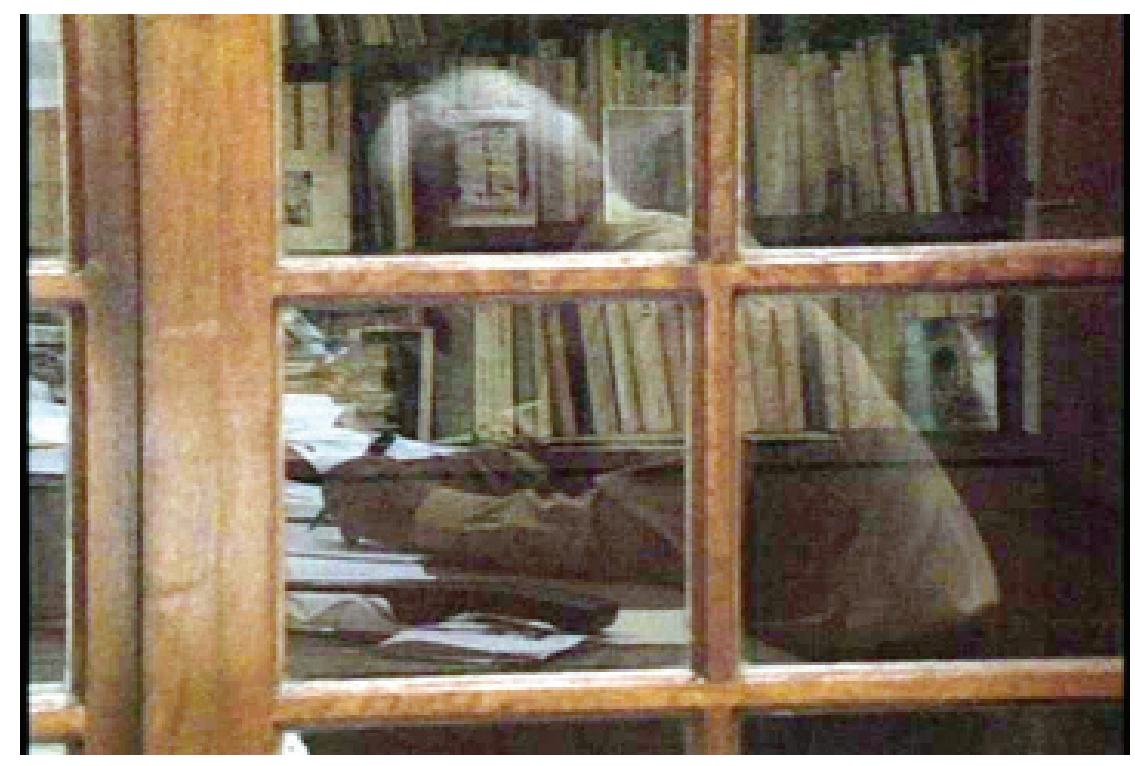

Vi skal videre til et andet dyr og et nyt vidnesbyrd. Men først et forberedende spørgsmål: Hvad mener vi, når vi siger (hvis vi siger): "Vi er også dyr"? Kropslighed, seksualitet, parringslyst? Hvad føler vi, når vi tænker på vor dyriskhed? Ubehag? Spænding? Angst eller fryd? Hvad har vi til fælles med dyr? Vi antropomorficerer ganske vist: Et dyr, og i al fald mit dyr, er empatisk, intelligent og kærligt; det viser mig betingelsesløs kærlighed, det har et sanseapparat, som gør os mennesker primitive i sammenligning. "Jo mere jeg ser af menneskene, desto gladere bliver jeg for dyrene," som en eller anden moralist sagde. Og han tænkte vel blandt andet på det bestialske, som på trods af sin etymologi er forbeholdt mennesker. Dyrs voldelighed er uskyldig, vi anser kun mennesket for at være i stand til overlagt grusomhed, kun mennesket har fri vilje til at handle overlagt og evne til at nyde vold. Men denne grænse, som jeg nu har trukket op, er kun en af mange og er egentlig selv både mange og flydende. Den dominerende grænse mellem dyr og menneske derimod, har filosofferne etableret med den største grundighed. Der bliver dyret den absolut anden, som kun tilsyneladende kan føle smerte, angst, utryghed og forladthed. Dyr har ikke sprog, sproget er særegent for mennesket, ergo er dyr maskiner, og rædselsskrigene fra hunden, som dissekeres levende, er en ren refleks. Filosofihistorien (Descartes, Kant, Heidegger og de andre) er også historien om menneskets argumentation for at behandle dyr på en bestialsk måde.

Dette var emnet for Derridas forelæsning i Cerisy den 15. juli 1997, hvor han fejrede sin 67-års fødselsdag med hele dagen at snakke om dyr, kun afbrudt af måltiderne (hvor vi godt nok spiste dyr, javist, dette handler ikke om at blive vegetarer: vi er kødædende, og desuden spiser vi til stadighed hinanden symbolsk, ikke mindst 
i kærligheden). Forskellen mellem filosofi og poesi, sagde han indledningsvist, er, at tænkning over dyr har været poesiens sag; i filosofien er en sådan tænkning - som tager dyr i betragtning som levende og agerende væsner - praktisk talt fraværende. Den mulige kontinuitet mellem menneske og dyr har altid været genstand for filosofiens ligegyldige eller hadefulde fornægtelse. Titlen på Derridas forelæsning var L'animal que donc je suis, en formulering som man kan se mobilisere mindst fire betydninger. Her er 1) en sarkastisk hilsen til Descartes og de filosoffer, som følger i hans spor; 2) en erkendelse af eget slægtskab med dyrene; 3) en indrømmelse af egen dyriskhed; 4) en henvisning til skabelsesberetningen, hvor mennesket kommer efter dyrene og bliver sat til at give dem navn og herske over dem. Alt dette måtte det tage mindst en dag at komme igennem, og ved sengetid var dyrets absolutte alteritet grundigt dekonstrueret.

Men før han pillede filosoffernes snedige bygningsværk fra hinanden, indviede han os i en hemmelighed. Et vidnesbyrd om erfaringen af at blive betragtet nedefra og skamme sig. Normalt, når vi føler skam og skyld, er det, fordi vi bliver set på ovenfra og ned. Men her står filosoffen nøgen i badet og bliver overrasket af sin kat, en hunkat naturligvis. Katten retter blikket mod kønnet, lader det så glide opover og ser ham lige ind i øjnene. Filosoffen erkender, at han er nøgen, og han føler skam, modvilligt. Skammer sig over sin egen blyhed: Det er jo bare et dyr. Hvordan kan et dyr se mig ind i øjnene, ansigt til ansigt? Har dyr ansigt? Det er en hunkat, er hun jaloux? (Hun hed Lucrèce og døde nogle år senere.) Vurderer hun mig, eller er blikket bare afventende, åbent, måske tankefuldt? Så mange spørgsmål og en så rungende tavshed og mangel på svar. Filosoffen oplever nøgenhedens passivitet, han underkastes et andet dyr. Samtidig minder kattens bundløse blik om den nøgne sandhed i ethvert blik.

Et helt andet dyr. Ikke min næste eller min bror. Men er det så enkelt? Derrida lader først Alice, heltinden i Lewis Carrolls eventyr, repræsentere den cartesianske ånd som et præliminært pædagogisk eksempel. Det har ikke noget formål at snakke med katte, klager Alice, de mjaver, eller de spinder, og man ved aldrig, om det betyder ja eller nej. Hvordan kan man snakke med nogen, som altid siger det samme? Alice er utrolig naiv, kommenterer Derrida, hun lader til at tro, at når det gælder mennesker, kan man i hvert fald skelne mellem et ja og et nej. At det altid er muligt at opfatte, om et menneske siger ja eller nej.

Nu er der selvfølge ikke tale om at få dyr til at snakke, det ville være en projicering. Men det er også tåbeligt at fratage et dyr enhver evne til at fremstå og manifestere sig. Der er i det hele taget ingen ende på filosoffernes tåbeligheder, når man først begynder at gå dem efter i sømmene, selv når de laver den mest "sømløse" diskurs. Walter Benjamin, for eksempel, betragter dyrenes tavshed som udtryk for dyb tristhed (Traurigkeit). Dyr er triste, fordi de ikke kan snakke, og fordi de bare har fået navn, de kan ikke give sig selv navn - deres eget navn. Derrida kommenterer tørt, at det vist også gælder for os mennesker, at vi har fået vores navn. Et andet eksempel er Heidegger, som siger i Sein und Zeit, at det er et problem, hvis et Nur-Lebenden (et dyr) "har tid", hvis det er konstitueret af tid. Jeg tror, at jeg forstår dette, når jeg læser det, siger Derrida, dette "som bare lever", det "rene" liv, og intet andet. Jeg forstår det på overfladen, det vil sige, jeg forstår, hvad dette gerne havde 
villet sige, hvad den, som siger det, ønsker at sige med det, men samtidig forstår jeg ingenting. "Livet i ren form" er et pseudobegreb, det er "ren" filosofi og et symptom på filosoffernes historie om "dyr", eftersom dette ord (dyr) for dem i praksis er en abstraktion og netop bare et ord (animal-animot).

For omkring 200 år siden sagde Jeremy Bentham, at spørgsmålet ikke er, om dyr kan tænke eller tale, men om de kan lide. Derrida gentager Benthams spørgsmål: Can they suffer? Ja, det er klart, at de kan, for den som vil se eller høre. Det er åbenbart, at dyr kan lide, at de bliver bange og skrækslagne. Men det er også vigtigt at understrege, at der ikke er tale om at nedrive grænsen mellem Mennesket (som forholder sig til sig selv ved at fortælle om sig selv, ved at etablere sin historie) og Dyret. Mellem menneskene og de andre, som vi kalder dyr, og som der findes mange slags af. Der er en diskontinuitet her, en heterogenitet: forskel, afvigelse, forskydning, brud. Grænsen er imidlertid ikke nogen lige linje, snarere er den en afgrund, uendelig dyb. Afgrundens rand er mangfoldig, der er mange forskellige randzoner, og på den anden side af afgrunden - længere væk fra mennesket, men ikke kun på én side - er ikke "dyret", men mange slags levende, både levende og døde, og mange slags "riger".

En gang i løbet af seminaret i Cerisy fik Derrida spørgsmålet om, hvor denne pludselige interesse for dyr kom fra? Derrida vender sig, opbragt, mod vedkommende og udbryder: Pludselig? Skulle det være noget nyt? Han havde da altid talt om dyr, direkte eller indirekte; indskrevet dem i sine bøger helt fra begyndelsen: Sporet, mærket, skriften, grafemet, gramma, alle disse begreber går allerede ud over dikotomien menneskelig/ikke-menneskelig.

Desuden er grænsen mellem mennesker og dyr eksplicit blevet udforsket og udfordret i flere sammenhænge (L'écriture et la différence, Glas, De l'esprit, Spectres de Marx, Apories...). For nylig er første del af Derridas seminar 2001-2003 ved École des Hautes Études en Sciences Sociales, La bête et le souverain, udkommet posthumt. Som titlen antyder, ser Derrida en analogi mellem dyret og herskeren, og helt specielt i deres forhold til loven, som de begge står uden for eller over.

Tænkningen over dyr har poesien taget sig af. Undringen, kan vi tilføje, over den andens fremmedhed som en spejling af os selv er et konstant træk ved læsningen af al stor digtning. Gentag efter mig, siger digtet. Opmærksomt ser vi ind i den andens øjne, den anden som er i vor umiddelbare nærhed og samtidig på den anden side af grænsen. Mekanisk gentager vi den andens rytme "med hjertet". Derridas filosofi har altid også været grænsepasseringer, og hans tænkning over dyr en af de tydeligste måder, erfaringerne fra sådanne ingenmandslande artikuleres på. Måske er det mere end noget andet sted her, vi lærer at læse.

Oversat fra norsk af Jacob Lund

\section{Litteratur}

Derrida, Jacques (1989): Che cos'è la poesia? i PO\&SIE 50, Paris, pp. 109-112. 
Derrida, Jacques (1998): Demeure. Maurice Blanchot, Paris : Galilée.

Derrida, Jacques (2006): L'animal que donc je suis, Paris: Galilée.

Derrida, Jacques (2008): Séminaire. La bête et le souverain, vol. I (2001-2002), Paris: Galilée.

Derrida, Jacques og Elisabeth Roudinesco (2001): De quoi demain... Dialogue, Paris: Fayard/Galilée. 